\title{
Analysis of the water balance under regional scenarios of climate change for arid zones of Colombia
}

\author{
Jesús Efrén OSPINA-NOREÑA, ${ }^{\mathrm{a}^{*}}$ Carlos Alberto DOMÍNGUEZ-RAMÍREZ, ${ }^{\mathrm{a}}$ \\ Emel Enrique VEGA-RODRÍGUEZ, ${ }^{\mathrm{b}}$ Aquiles Enrique DARGHAN-CONTRERAS, ${ }^{\mathrm{a}}$ \\ and Luis Ernesto RODRÍGUEZ-MOLANO ${ }^{\mathrm{a}}$
}

\author{
${ }^{a}$ Facultad de Ciencias Agrarias, Departamento de Agronomía, Universidad Nacional de Colombia, Carrera 30 núm. \\ 45-03, Edificio 500, Bogotá D. C., Colombia \\ ${ }^{b}$ Facultad de Ciencias, Universidad Nacional de Colombia, Carrera 30 núm. 45-03, Edificio 476, Bogotá D. C., \\ Colombia \\ *Corresponding author; jeospinan@unal.edu.co
}

Received: October 9, 2016; accepted: December 7, 2016

\begin{abstract}
RESUMEN
En este trabajo se analizan en detalle los parámetros implicados en el balance hídrico. Se consideran las condiciones actuales y el cambio climático en una zona representativa de clima árido en Colombia: la región desértica de Uribia en el departamento de La Guajira. Con este fin se seleccionaron algunas estaciones climatológicas que, de acuerdo con los valores registrados de temperatura y precipitación, pueden considerarse representativas de áreas climáticas áridas o desérticas según el índice de Lang $\left(\mathrm{PCP} / \mathrm{T}_{\mathrm{avg}}\right)$. Se construyó una línea de referencia a partir de los registros históricos de precipitación y temperatura y se analizó su comportamiento. Los datos de las estaciones se obtuvieron de la base de datos del Instituto de Hidrología, Meteorología y Estudios Ambientales de Colombia. Después de calcular los escenarios de referencia, se estimó el balance hídrico actual tomando en cuenta las variables originales e incluyendo, cuando fue necesario, nuevos parámetros para el cálculo de la ecuación simplificada de continuidad. El análisis incluyó parámetros como potencial de evapotranspiración, humedad del suelo, almacenamiento o recarga y sus cambios, déficit y exceso hídrico, escorrentía, periodos de recarga y uso del agua. Las anomalías de temperatura y precipitación se calcularon tomando en cuenta los nuevos escenarios climáticos "trayectorias representativas de concentración" para diferentes periodos (de corto y largo plazo). Con las anomalías encontradas se ajustó la línea de referencia para las variables mencionadas anteriormente, y los parámetros asociados se analizaron en el contexto del balance hídrico. En escenarios de cambio climático, el balance hídrico proyecta una posible intensificación de las condiciones desérticas en la región de Uribia-Guajira, ya que se espera una disminución en el índice de Lang de su valor actual de 18.7 (desértico) a 17 en 2050 y 14.5 en 2070, como resultado de una reducción de las precipitaciones (2.4 y 11\%) y un incremento de la temperatura anual promedio de alrededor de 1.7 ${ }^{\circ} \mathrm{C}$ con el modelo HadGEM2-ES para el periodo $2041-2060$ y de $3.7^{\circ} \mathrm{C}$ con el modelo GFDL-CM3 para el periodo 2061-2080. Esto se comprueba mediante la clasificación climática de Thornthwaite, que tipifica el área de estudio como una zona árida con recursos hídricos limitados y sin excedentes. Este déficit podría acarrear graves consecuencias ambientales, problemas sociales y declinación de la productividad agrícola e industrial de la región.
\end{abstract}

\begin{abstract}
This work discusses in detail the parameters involved in water balance. The analysis is performed by considering the current conditions and climate change in a climatic zone that represents the arid regions of Colombia: The municipality of Uribia (desert) in the state of La Guajira. For this purpose, some climatological stations, which by their reported values of temperature and precipitation can be considered representative of the arid or desert climatic zones according to the Lang's index ( $\left.\mathrm{PCP} / \mathrm{T}_{\mathrm{avg}}\right)$, were selected. Then, with
\end{abstract}


historical temperature and precipitation values registered at the station of the area, the baseline was built and its behavior analyzed. The station data were obtained from the database of the Instituto de Hidrología, Meteorología y Estudios Ambientales (Institute of Hidrology, Meteorology and Environmental Studies) of Colombia. After estimating the baseline scenarios, the current water balance on the site was calculated by taking into account the original variables and including new parameters, if necessary, for the calculation of the simplified continuity equation. The analysis included parameters such as potential and actual evapotranspiration, moisture of soil, storage or recharge and their changes, water deficit and excess, runoff, periods of recharge, and water use. Anomalies in temperatures $\left({ }^{\circ} \mathrm{C}\right)$ and precipitation were calculated by taking into account the new climate scenarios "representative concentration pathways" for different periods (short- and long-term). With the anomalies identified, the baseline for the above-mentioned variables was adjusted. Again, the associated parameters were analyzed and discussed in the context of water balance. In climate change scenarios, the water balance projects a prospective exacerbation of desert conditions in the Uribia-Guajira region, since a decrease in the Lang's index from its current value of 18.7 (desert) to 17.0 in 2050 and 14.5 in 2070 is expected, as a consequence of a decrease in precipitation (2.4 and 11.0\%) and an increase in annual temperature of about $1.7^{\circ} \mathrm{C}$ with the HadGEM2-ES model for the period $2041-2060$ and $3.7^{\circ} \mathrm{C}$ with the GFDL-CM3 model for the period 2061-2080. This can be verified by means of the Thornthwaite climate classification, which categorizes the area of study as an arid zone with limited and no excess of water. This deficit could lead to serious environmental consequences, social problems and a decline in the industrial and agricultural productivity of the zone.

Keywords: Cimate change, water balance, climatic scenarios, arid zones.

\section{Introduction}

According to the Intergovernmental Panel on Climate Change (IPCC, 2013), the increase of greenhouse gases in the atmosphere may have an influence on the mean global warming of the Earth's surface within the range of 0.5 to $1.3{ }^{\circ} \mathrm{C}$ during the period $1951-2010$. Regarding the natural internal variability, it is expected that average annual and seasonal temperature increases will be higher in the tropics and subtropics than in the mid-latitudes. For the period 2081-2100, the average Earth's temperature is expected to be in the ranges derived from the new climate change scenarios brought into consideration, that is, with increases of $0.3-1.7^{\circ} \mathrm{C}$ (RCP 2.6), 1.1-2.6 ${ }^{\circ} \mathrm{C}$ (RCP 4.5), 1.4-3. $1^{\circ} \mathrm{C}$ (RCP 6.0), and $2.6-4.8^{\circ} \mathrm{C}(\mathrm{RCP} 8.5)$. Likewise, by the end of the century the average annual precipitation estimated for the RCP 8.5 scenario is expected to increase in high latitudes and in the equatorial Pacific Ocean, while it could decrease in many dry zones in mid-latitudes and subtropics. This scenario also suggests huge impacts in zones with climates similar to the study area. Arid and semi-arid regions in mid-latitudes and subtropics are likely to have less rain, hence, it is estimated that for each degree of global warming, approximately $7 \%$ of the global population will be exposed to a reduction of at least 20\% in hydric resources (IPCC, 2013, 2014; Jiménez Cisneros et al., 2014).

This results in alterations of the hydrological cycle, such as increase or reinforcement of evaporation due to higher temperatures, and an increase in actual, global and regional evapotranspiration, which will be affected by variations in precipitation levels, spatiotemporal changes in rain distribution, values of daily temperature, aerosols concentration, alteration of net radiation, vapor pressure deficit, and wind speed (IPCC, 2007; Bates et al., 2008; Fu et al., 2009; McVicar et al., 2010; Miralles et al., 2011; Wang A. et al., 2011; Kundzewicz et al., 2007). These features could have a negative influence on the water sources.

Among the main factors that have an effect on the natural water supply and its quality, other than climate, we may find change in land use, water damming for different activities, polluting emissions in the atmosphere, treatment of wastewater, and social, economic and technological changes and their respective relations, including lifestyle changes (van Vuuren et al., 2012; IPCC, 2007). Furthermore, the demand of the hydric resource for its use and consumption directly affects the demographic factor, food security and sovereignty, politics, economy, technology, lifestyle and water consumption priorities (IPCC, 2007). Among these non-climatic factors, land use change stands out, since it could significantly affect drinking water systems. For example, soil degradation attributable to urban activities could increase the risks of floods and decrease the aquifer recharge, due to the settlement of communities near the channels or the limitation of recharge from natural ground currents 
as a consequence of compaction or other impacts resulting from urbanization, apart from disturbing the natural systems. Similarly, regarding freshwater systems, using land for agriculture in the future, in particular for irrigation, which represents almost $90 \%$ of the global demand of water, will severely impact its availability for domestic use and the proper functioning of ecosystems (Döll, 2009).

Groundwater systems change at a slower pace than water available in the surface. Studies regarding climate change to assess and analyze groundwater systems are limited, information is scarce and there is no access to the databases necessary for their study and analysis. Meanwhile, droughts affect agriculture in terms of quality and quantity, having a direct influence on food security and sovereignty, water supply for the consumption of different productive sectors and others. Semi-arid and semi-humid regions around the world as Australia, the west of the USA, the south of Canada and the Sahel have suffered very long droughts -in some cases during many years with different intensities - but climate change can affect them, since it is expected that drought conditions increase by about $30 \%$ by the end of the century (Kundzewicz et al., 2007).

In Colombia, according to the Instituto de Hidrología, Meteorología y Estudios Ambientales (Institute of Hidrology, Meteorology and Environmental Studies) (IDEAM, 2010), in the state of Guajira and some other regions of the Caribbean, there are areas where water is highly deficient, e.g., to the south of the Sierra Nevada de Santa Marta and in the sub-basins of the Magdalena and Cauca rivers, corresponding to the high parts of the basin; to the Savannah of Bogotá; to the Alto Cauca, and to the basin of the Chicamocha river. When a dry climatic condition occurs (average year), the water yield reduces significantly as compared to normal conditions. In particular, a significant reduction is observed in the Caribbean, more specifically in the Guajira.

The natural supply (availability) of the hydric resource in an average year and a dry year has regional differences that are important to discriminate. In the hydrographic area of the Caribbean, the reduction of the natural supply of this resource varies for these conditions between $46 \%$ in Atrato-Darién and $73 \%$ in Catatumbo. Within the same area, in the Urabá Antioqueño this difference is of $68 \%$, in Sinú of $59 \%$, and in the Guajira of 63\% (IDEAM, 2010).
On the other hand, IDEAM (2015a) suggests that the main reductions in precipitations by the end of the century will occur in the states of San Andrés and Providencia, Magdalena, and Guajira. This report also estimates that in the average ensemble scenario, potential droughts may occur in the north of Cesar, Magdalena and Guajira by 2100 . Furthermore, it is suggested that the probability of a shortage of food harvested in the region could increase. The hydric shortage could affect sectors such as agriculture, and in particular stockbreeding, as well as the energy and tourism sectors in the Caribbean (IDEAM, 2015a).

This study aims to determine the water balance under climate change scenarios (RCP 4.5 and RCP $8.5)$ in two periods of time (2041-2060 and 20612080), based on the validation and modeling of the climatic and hydrologic parameters that are distinctive of a region which represents extreme desert conditions in Colombia, in order to describe the impact of surface and groundwater availability on ecosystems, domestic use, and the productivity of the primary and industrial sectors.

\section{Materials and methods}

\subsection{Description of the study area}

An area that represents the arid and desert conditions in Colombia was selected in order to analyze and assess the parameters involved in water balance and the effects of climate change in such region. The area selected corresponds to a desert zone initially classified according to the Lang's index $\left(\mathrm{I}_{\mathrm{L}}\right)$ or the ratio between annual precipitation (PCP) and average temperature $\left(\mathrm{T}_{\mathrm{avg}}\right)$ (Table I), located in the municipality of Uribia in the state of Guajira.

To describe the climate in the study area and elaborate its baseline, a climatological station was selected, which represented the zone and also had

Table I. Climatic zones according to Lang's index (PCP/ $\mathrm{T}_{\text {avg }}$ ).

\begin{tabular}{ll}
\hline $\mathrm{I}_{\mathrm{L}}$ & Zone \\
\hline $0-20$ & Desert \\
$20-40$ & Arid \\
$40-60$ & Wet zone of steppe and savannah \\
$60-100$ & Wet zone of sparse forest \\
$100-160$ & Wet zone of dense forest \\
$>160$ & Very wet zone of grassland and tundra \\
\hline
\end{tabular}

Source: Almorox, 2003. 
historical records with relevant variables, such as $\mathrm{T}_{\mathrm{avg}}$, maximum and minimum temperature $\left(\mathrm{T}_{\max }\right.$, and $\mathrm{T}_{\min }$, respectively), $\mathrm{PCP}$, and evaporation (Ev), among others. The baseline covers the period between 1976 and 2005. The data were obtained from the IDEAM database.

\subsection{Calculation of water balance parameters in normal conditions}

Water balance is considered an essential tool to locate and establish crops, track their growth and development, and program and perform hydraulic infrastructure works (e.g., infrastructure for irrigation and drainage, program activities for management and irrigation, etc.). If, for example, water availability to perform agricultural activities in any location depends on precipitation and its resupply of moisture to the soil, the fluctuations between precipitation and evapotranspiration (which are essential components for water balance), will influence the availability of water for the crops.

In order to assess the parameters involved in water balance (other than the variables already analyzed), it is necessary to consider the potential evapotranspiration (ETo). To calculate ETo, the FAO Penman-Monteith method was taken into account (FAO, 209), which is the only method recommended to determine ETo with climatic parameters (Eq. 1).

$$
E T o=\frac{0.408 \Delta(R n-G)+\gamma \frac{900}{T+273} U_{2}\left(e_{s}-e_{a}\right)}{\Delta+\gamma\left(1+0.34 U_{2}\right)}
$$

where ETo represents the baseline evapotranspiration $\left(\mathrm{mm} \mathrm{day}^{-1}\right), R_{n}$ the net radiation in the crop surface $\left(\mathrm{MJ} \mathrm{m}^{-2}\right.$ day $\left.^{-1}\right), G$ the soil heat flow $\left(\mathrm{MJ} \mathrm{m}^{-2}\right.$ day $\left.^{-1}\right)$, $T$ the air average temperature at a $2-\mathrm{m}$ height $\left({ }^{\circ} \mathrm{C}\right)$, $U_{2}$ the wind speed at a $2-\mathrm{m}$ height $\left(\mathrm{m} \mathrm{s}^{-1}\right), e_{s}$ the saturation's vapor pressure $(\mathrm{kPa}), e_{a}$ the actual vapor pressure $(\mathrm{kPa}), e_{s}-e_{a}$ the vapor pressure deficit $(\mathrm{kPa})$, $\Delta$ the slope of the vapor pressure curve $\left(\mathrm{kPa}^{\circ} \mathrm{C}^{-1}\right)$, and $\gamma$ the psychrometric constant $\left(\mathrm{kPa}^{\circ} \mathrm{C}^{-1}\right)$.

The estimation was made with the help of the Cropwat 8.0 software, which requires location data, such as country, station, altitude, coordinates (longitude and latitude); it also requires climatic data such as maximum and minimum temperature, relative humidity, wind speed and insolation or hours of sunlight.
After obtaining the monthly value of PCP and ETo, other variables of the water balance were calculated. This consisted in defining the following parameters (in $\mathrm{mm}$ ): the difference between precipitation and evapotranspiration (PCP $-E T o[\Delta])$; the reserve or storage of usable water $\mathrm{R}$ (Sto); the deficit, excess, and variation in the reserve or storage of usable water (Def, Exc and $\Delta \mathrm{R}[\Delta$ Sto], respectively); the actual evapotranspiration; the replacement $(\mathrm{R})$; and the usage (U).

Hence, it was verified if ETo was higher or lower than PCP in the period considered $(\mathrm{PCP}-E T o=\Delta)$. The difference or result classified the months as follows: dry months if (PCP $-E T o<0)$ and humid months if (PCP $-E T o>0)$. To define the R(Sto) of usable water, the following is taken into account: when more inputs than outputs are produced in a month, $(\mathrm{PCP}>E T o)$, surplus water will increase the soil reserve; on the contrary, if there are more outputs than inputs, the soil reserve will decrease.

At this point, it is important to emphasize that the reserve or storage of usable water in the soil is not uniform; it depends on the type and characteristics related to the different types of soil. In this particular case, taken as a climatic reference for the study area, the maximum capacity of reserve or storage of water (field capacity [FC]) is $100 \mathrm{~mm}$. Thus, $\mathrm{R}$ can only have values between 0 (dry soil, without water available for plants) and 100 (optimal humidity content).

Initially, the month when the positive $\Delta$ period starts was identified, and a value of 100 was assigned to it. Some authors propose that a hypothetical value should be assigned to a month and annual calculation cycles should be conducted until reaching the suggested hypothesis.

For calculation purposes, it is usually assumed that after a dry period the soil reserve is null (0). As a result, the calculation of $\mathrm{R}$ begins with the first humid month and the previous month receives a null (0) reserve. Then, next month's R or Sto are calculated by adding the previous month's R to $\mathrm{PCP}-E T o=\Delta$ of the current month (Eq. 2)

$R_{i}=R_{i-1}+\left(P C P_{i}-E T o_{i}\right)$

If the result is more than 100 , then $R=100$ and the rest transfers to Exc. If $R$ goes between 0 and 100, it takes that value (result); and if the result is less than 
$0, R$ is $=0$ and the value (result) transfers to Def. The rules are based on $R_{i}$; in other words, $R_{i}=R_{i-1}+$ $\left(\mathrm{PCP}_{i}-E T o_{i}\right)$ if $0<R_{i-1}+\left(\mathrm{PCP}_{i}-E T o_{i}\right)<\mathrm{R}_{\text {max }} ; R_{i}$ $=R_{\text {max }}$ if $R_{i-1}+\left(\mathrm{PCP}_{i}-E T o_{i}\right)>R_{\text {max }}$; and $R_{i}=0$ if $0>R_{i-1}+\left(\mathrm{PCP}_{i}-E T o_{i}\right)$. Later, the variation between the reserve and the storage of usable water $(\Delta \mathrm{R}$ or $\Delta$ Sto) is calculated based on the result of the difference between the value of storage of usable water of the month considered and the last month. If the sign is positive, it means the replacement $(\mathrm{R})$ of the soil moisture, and if the sign is negative, it means the utilization (U) of the soil moisture $\left(\Delta R_{i}=R_{i}-R_{i-1}\right)$.

Finally, ETa is determined. The following cases can occur each month: If $\mathrm{PCP} \geq E T$, then $E T a=$ $E T o$; and if $\mathrm{PCP}<E T o$, then ETa $=\mathrm{PCP}+\mid \Delta$ Sto $\mid$. The coefficient ETa/ETo determines the growth periods, considering that the months with ETa/ETo $\geq$ 0.60 are appropriate to develop crops, although it is necessary to estimate each coefficient for every crop and phenological stage.

\subsection{Climate classification by the Thornthwaite method}

After conducting the water balance, climate classification was performed according to the Thornthwaite method as follows.

\subsubsection{Moisture index}

According to Thornthwaite, the humidity or aridity of a climate can be expressed in terms of the water excess index $\left(\mathrm{I}_{\mathrm{h}}\right)$ and the aridity index $\left(\mathrm{I}_{\mathrm{a}}\right)$, for which the following equations are used:

$I_{h}=(\mathrm{Exc} / \mathrm{ETo}) \bullet 100$

$I_{a}=(\mathrm{Def} / \mathrm{ETo}) \cdot 100$

Since the excess or lack of water generally occur in different seasons or periods, both should have a moisture index $\left(I_{m}\right)$, positively affecting the first one and negatively the second one, like this:

$I_{m}=I_{h}-I_{a}=(100 \cdot \mathrm{Exc}-100 \cdot \mathrm{Def}) /$ ETo

Positive values of $I_{m}$ correspond to humid climates, while negative values of $I_{m}$ determine dry climates; the ranges and classification of types of climates in accordance with $I_{m}$ values are presented in annex A1.

\subsubsection{Seasonal variation of the effective humidity} The moisture index can indicate how humid or arid a region is, but it cannot differentiate the seasonal variations; therefore, in humid climates $\left(I_{m}>0\right)$ it could be necessary to determine whether there are dry seasons and assess the drought degree, while in dry climates $\left(I_{m}<0\right)$ it could be necessary to determine whether there are humid seasons and assess the humidity degree. Annex A2 presents the subdivisions for humid climates $\left(\mathrm{A}, \mathrm{B}, \mathrm{C}_{2}\right)$ and dry climates $\left(\mathrm{C}_{1}\right.$, D, E).

\subsubsection{Index of thermal efficiency}

The potential evapotranspiration is a thermal efficiency index, and it can be considered as a climate factor that involves the day length and temperature. This index enables the differentiation between mesothermal and megathermal climatic zones. Classifications based on this index are comparable to those derived from the moisture index; thus, they are designated by similar symbols (see annex A3).

\subsubsection{Thermal efficiency concentration during the summertime}

In equatorial zones, where the day length is approximately the same during the whole year and temperature is also uniform (thermal fluctuations are small), the ETo seasonal variation will be slight; similarly, ETo corresponding to any three consecutive months will be approximately $25 \%$ of the annual ETo.

The thermal efficiency concentration can be calculated using the next equation:

$E C=(E T o v / E T o) * 100$

where EC is the thermal efficiency concentration during summer, $E T o_{v}$ the evapotranspiration of the three summer months, and ETo the annual evapotranspiration. Annex A4 shows the different thermal floors according to the thermal efficiency concentration in summer.

\subsection{Calculation of the water balance parameters in climate change conditions}

The baselines of the main variables were adjusted with the anomalies projected in the study area through the HadGEM2-ES and GFDL-CM3 models, RCP 4.5 and RCP 8.5 scenarios, for the periods 2041-2060 (focused on 2050) and 2061-2080 (focused on 2070), 
respectively. These scenarios and periods were selected because the first results of a preliminary assessment of Lang's index suggested an optimistic scenario, while the second results implied a pessimistic scenario for the region. The projected anomalies were retrieved from the scenarios provided by WorldClim Global Climate Data with a 2.5 min latitude and longitude resolution equivalent to about $4.5 \times 4.5 \mathrm{~km}$, which are available at http://www.worldclim.org/cmip5_2.5m. Afterwards, a reassessment of other variables and parameters involved in water balance and the classification by the Thornthwaite method was conducted.

\section{Analysis and results}

The station selected was Nazareth, located at $72^{\circ}$ $15^{\prime} 57^{\prime \prime} \mathrm{W}, 11^{\circ} 42^{\prime} 50^{\prime \prime} \mathrm{N}$ in the state of Guajira (Fig. 1). Studies in this zone are critical, since the potential effects of climate change could certainly exacerbate the already deficient conditions, threatening the natural supply of water, its accessibility and all the activities that depend on this resource, increasing the gap between the natural supply and the constantly growing demand for the resource. This would increase the index of pressure over the resource and encourage or lead to conflicts.

As mentioned above, the $\mathrm{I}_{\mathrm{L}}$ for the area selected was $\mathrm{I}_{\mathrm{L}}=510.2 / 27.3=18.7$, which classifies it as a desert zone according to Lang's climatic zones classification (see Table I).
Analysis of the values collected at the station enabled us to determine why the study area has a $\mathrm{T}_{\max }$, $\mathrm{T}_{\text {avg }}$ and $\mathrm{T}_{\min }$ of $32.5,27.3$ and $22.0{ }^{\circ} \mathrm{C}$, respectively (Fig. 2a). Even though PCP is scarce (about $510.2 \mathrm{~mm}$ ), evaporation and evapotranspiration are higher than 2044.5 and $1521.1 \mathrm{~mm}$, respectively (Fig. 2b) (the latter figure accounts for extreme desert conditions).

Figure 2 shows the monthly behavior of the temperature, precipitation and evaporation variables analyzed in the station. It exhibits the current monthly values (baseline) of the main variables.

As mentioned above and can be observed in Fig. 2 and Table II, extreme conditions exist in all the variables in the state of Guajira, which has direct influence on arid conditions, access to water and other parameters and variables related to the hydric resource and, certainly, on the activities and sectors that depend on it (particularly the primary sector, i.e., agriculture, livestock, forestry).

In Figure $2 b$ it is evident that in the municipality of Uribia evaporation basically exceeds by far the values of precipitation all year round.

Table III shows the results of applying the explained procedure to calculate water balance in the study area.

It is worth noting that in the study area precipitation is scarce and ETo has a high rate that leads to a humidity deficit of $1010.9 \mathrm{~mm}$, which comprehends the period between January and September, without
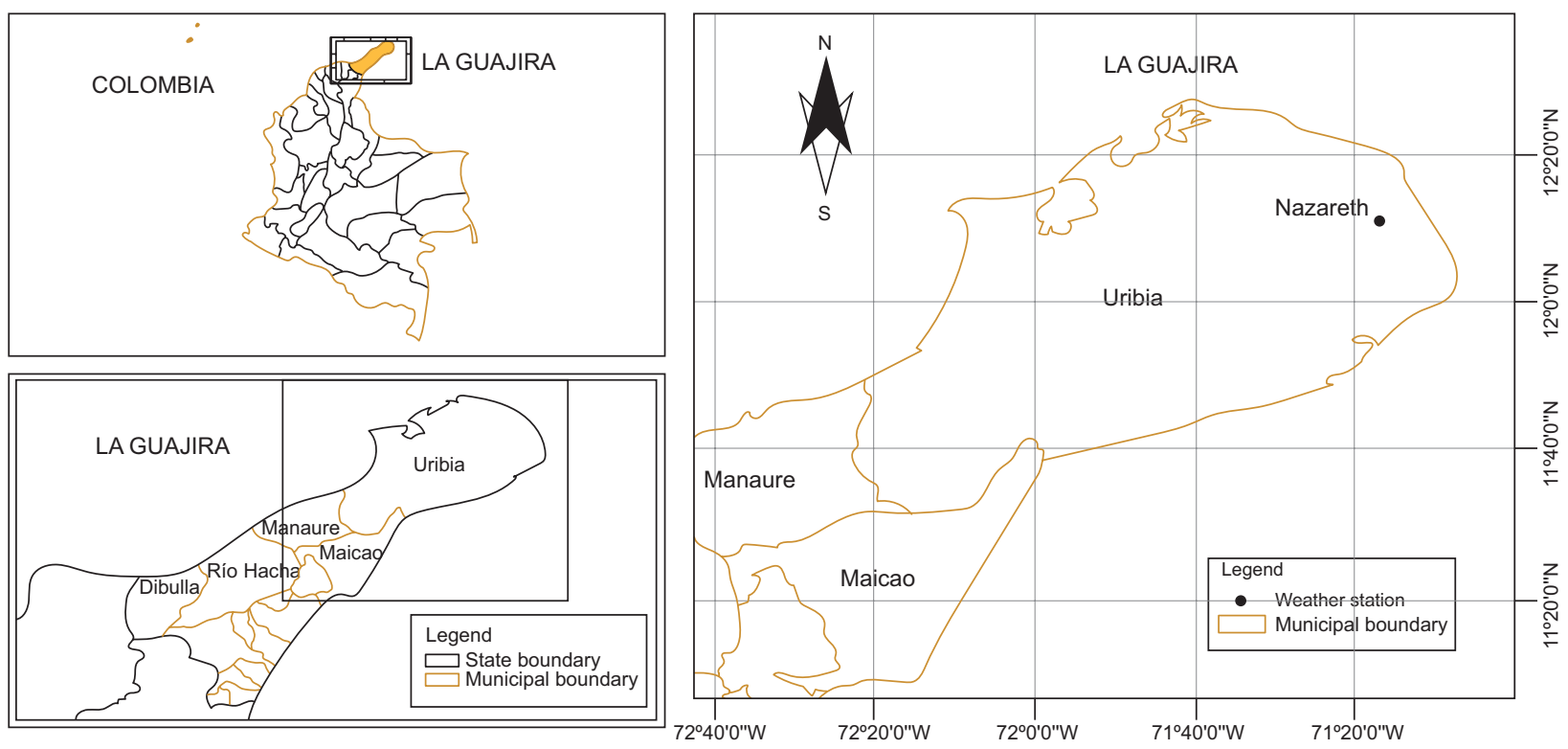

Fig. 1. Location of the study area (station analyzed, Nazareth). 

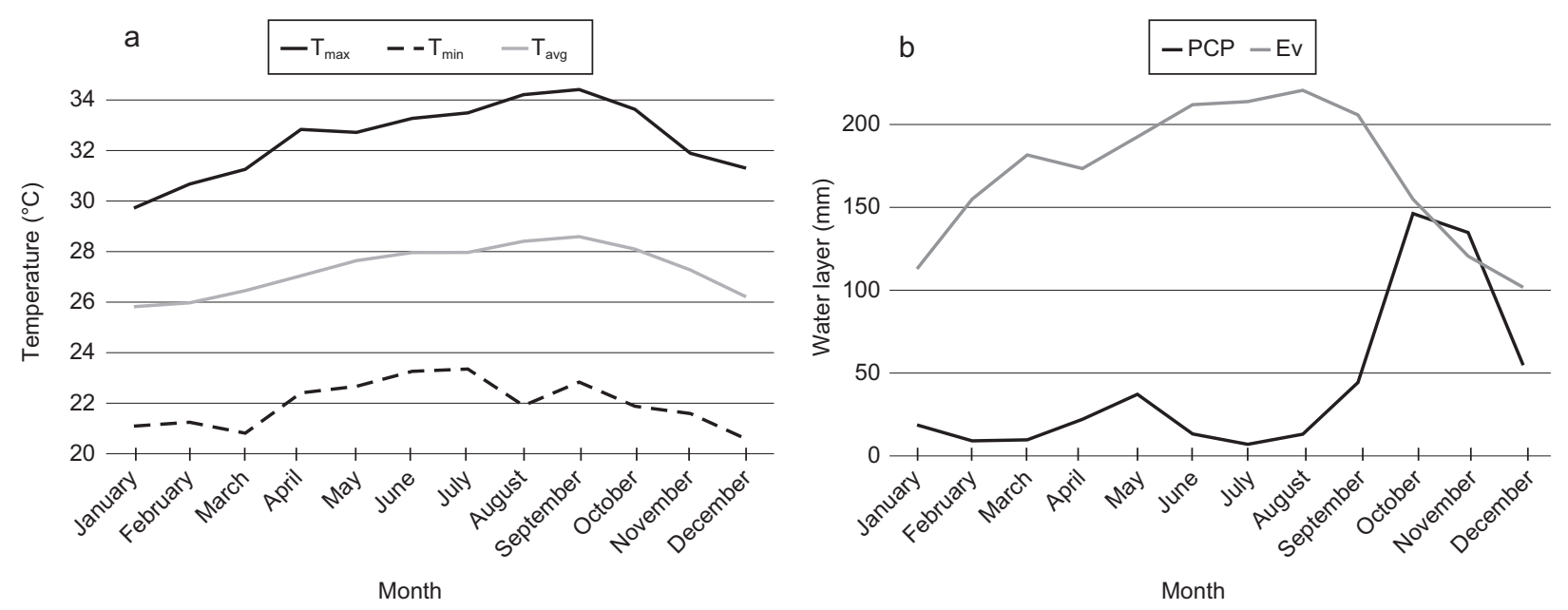

Fig. 2. (a) Monthly behavior of temperature at Uribia-Guajira. (b) Monthly behavior of precipitation and evaporation at Uribia-Guajira.

Table II. Monthly values baseline (January [J] to December [D])

\begin{tabular}{lccccccccccccc}
\hline V/month & J & F & M & A & M & Jn & Ju & A & S & O & N & D & Sum/avg \\
\hline $\mathrm{T}_{\max }\left({ }^{\circ} \mathrm{C}\right)$ & 29.7 & 30.7 & 31.3 & 32.8 & 32.7 & 33.3 & 33.5 & 34.2 & 34.4 & 33.6 & 31.9 & 31.3 & 32.5 \\
$\mathrm{~T}_{\min }\left({ }^{\circ} \mathrm{C}\right)$ & 21.1 & 21.2 & 20.8 & 22.4 & 22.7 & 23.3 & 23.4 & 21.9 & 22.8 & 21.9 & 21.6 & 20.6 & 22.0 \\
$\mathrm{~T}_{\text {avg }}\left({ }^{\circ} \mathrm{C}\right)$ & 25.8 & 26.0 & 26.5 & 27.0 & 27.6 & 28.0 & 28.0 & 28.4 & 28.6 & 28.1 & 27.3 & 26.2 & 27.3 \\
$\mathrm{PCP}(\mathrm{mm})$ & 18.7 & 9.1 & 9.7 & 22.1 & 37.2 & 13.3 & 7.0 & 13.1 & 44.3 & 146.2 & 134.8 & 54.7 & 510.2 \\
$\mathrm{RH}(\%)$ & 81.5 & 80.6 & 80.7 & 80.8 & 81.0 & 80.1 & 80.1 & 80.1 & 80.9 & 83.2 & 84.1 & 82.9 & 81.3 \\
$\mathrm{Ev}(\mathrm{mm})$ & 113 & 155 & 182 & 173 & 193 & 212 & 214 & 221 & 206 & 155 & 121 & 102 & 2044.5 \\
\hline
\end{tabular}

V: variable.

Table III. Current water balance at the Nazareth station (January [J] to December [D]).

\begin{tabular}{|c|c|c|c|c|c|c|c|c|c|c|c|c|c|}
\hline V/month & $\mathrm{J}$ & $\mathrm{F}$ & $\mathrm{M}$ & A & M & $\mathrm{Jn}$ & $\mathrm{Ju}$ & A & $\mathrm{S}$ & $\mathrm{O}$ & $\mathrm{N}$ & D & Total \\
\hline PCP & 18.7 & 9.1 & 9.7 & 22.1 & 37.2 & 13.3 & 7.0 & 13.1 & 44,3 & 146.2 & 134.8 & 54.7 & 510.2 \\
\hline $\mathrm{ET}_{0}$ & 105.5 & 111.5 & 131.8 & 122.4 & 131.4 & 140.5 & 151.3 & 155.0 & 142.2 & 125.5 & 106.3 & 97.9 & 1521.1 \\
\hline$\Delta$ & -86.8 & -102.4 & -122.1 & -100.3 & -94.2 & -127.2 & -144.3 & -141.9 & -97.8 & 20.7 & 28.5 & -43.1 & \\
\hline R Sto & 0.0 & 0.0 & 0.0 & 0.0 & 0.0 & 0.0 & 0.0 & 0.0 & 0.0 & 20.7 & 49.2 & 6.0 & \\
\hline Def & 80.7 & 102.4 & 122.1 & 100.3 & 94.2 & 127.2 & 144.3 & 141.9 & 97.8 & 0.0 & 0.0 & 0.0 & 1010.9 \\
\hline Exc & 0.0 & 0.0 & 0.0 & 0.0 & 0.0 & 0.0 & 0.0 & 0.0 & 0.0 & 0.0 & 0.0 & 0.0 & 0.0 \\
\hline$\Delta$ Sto & -6.0 & 0.0 & 0.0 & 0.0 & 0.0 & 0.0 & 0.0 & 0.0 & 0,0 & 20.7 & 28.5 & -43.1 & \\
\hline $\mathrm{ET}_{\mathrm{a}}$ & 24.7 & 9.1 & 9.7 & 22.1 & 37.2 & 13.3 & 7.0 & 13.1 & 44,3 & 125.5 & 106.3 & 97.9 & 510.2 \\
\hline $\mathrm{ET}_{\mathrm{a}} / \mathrm{ET}_{0}$ & 0.2 & 0.1 & 0.1 & 0.2 & 0.3 & 0.1 & 0.05 & 0.1 & 0,3 & 1.0 & 1.0 & 1.0 & \\
\hline $\mathrm{R}$ or $\mathrm{U}$ & U & & & & & & & & & $\mathrm{R}$ & $\mathrm{R}$ & U & \\
\hline
\end{tabular}

$\mathrm{V}$ : variable.

excess. There is only a water replacement rate of $20.7 \mathrm{~mm}$ and $28.5 \mathrm{~mm}$ in October and November, respectively; $43.1 \mathrm{~mm}$ are used in December and $6.0 \mathrm{~mm}$ in January. According to the ETa/ETo values presented in Table III, only the period from
October to December would be appropriate for the development of some crops. These aspects confirm the results of the comparison between PCP, Ev and ETo (Figs. 2b and 3) and to the observations made using $\mathrm{I}_{\mathrm{L}}$. 


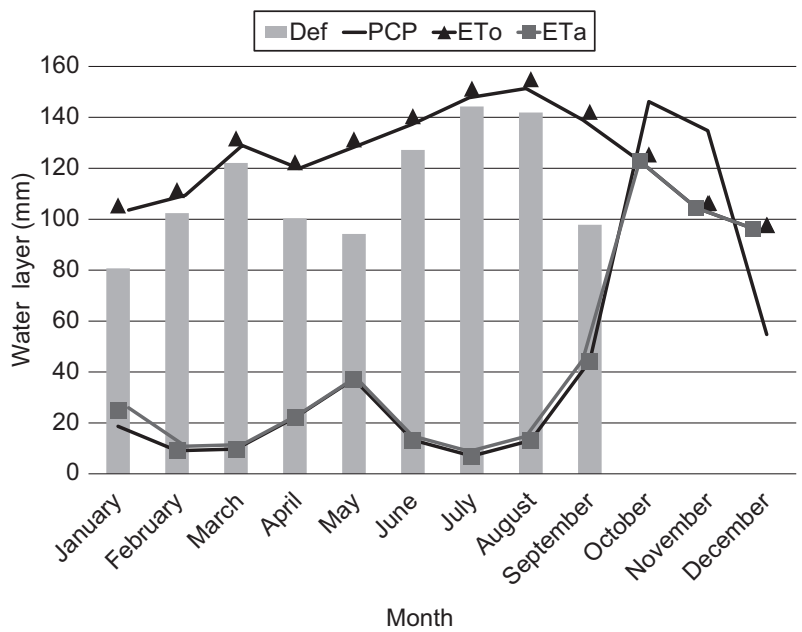

Fig. 3. Current water balance, municipality of UribiaGuajira.

Figure 3 shows the behavior of PCP, ETo, ETa, Def and Excx of water in the study area, as a result of water balance analysis under the current climatic conditions.

In Figure 3, the area between the ETo and Eta lines means a deficit. PCP above ETa corresponds to the storage in reserve plus excess; ETa over PCP means a utilization of the soil reserve.

A climate classification by the Thornthwaite method was conducted, taking into account the results in Table III, Eqs. (3-6) and annexes A1 to A4, which demonstrated that under current conditions, the study area classifies as an arid zone with limited or no excess of water, megathermal, and with a low concentration of thermal efficiency. Its symbolic description would be EdA'a' (see annexes A1 to A4), supporting the condition initially found when using $\mathrm{I}_{\mathrm{L}}$.

Table IV shows the values obtained for the indexes related to climate classification by the Thornthwaite method.

Table IV. Indexes for climate classification.

\begin{tabular}{lrcr}
\hline Index & Value & Index & Value \\
\hline $\mathrm{I}_{\mathrm{h}}=($ Exc/ETo $) \cdot 100$ & 0.0 & $\mathrm{I}_{\mathrm{m}}=\mathrm{I}_{\mathrm{h}}-\mathrm{I}_{\mathrm{a}}$ & -66.5 \\
$\mathrm{Ia}=($ Def $/$ ETo $) \cdot 100$ & 66.5 & $\mathrm{EC}=\left(\right.$ ETo $\left._{v} / E T o\right) \cdot 100$ & 29.5 \\
\hline
\end{tabular}

All the factors so far analyzed are of great importance, as already mentioned, when planning hydraulic infrastructure works, sowings and growing activities of any type of crops. Likewise, they allow leading activities such as management of hydrographic basins, irrigation programs, production forecast, climate classification, crops zoning, among others.

\subsection{Calculation of the water balance parameters under climate change conditions}

The baseline of the main variables involved in the calculation of water balance was adjusted with the anomalies projected in the study area through the HadGEM2-ES and GFDL-CM3 models, RCP 4.5 and RCP 8.5 scenarios, for the periods 2041-2060 (focused on 2050) and 2061-2080 (focused on 2070), respectively.

Table $\mathrm{V}$ shows the adjusted baselines, namely future scenarios for $\mathrm{T}_{\max }, \mathrm{T}_{\mathrm{avg}}, \mathrm{T}_{\min }, \mathrm{PCP}$ and $\mathrm{RH}$.

These scenarios suggest an annual reduction of $2.4 \%$ in precipitation within the study area for the HadGEM2-ES model (RCP 4.5, period 2041-2060), and $11.0 \%$ for the GFDL-CM3 model (RCP 8.5, period 2061-2080), moving from 510.2 to 498.2 and 510.2 to $454.2 \mathrm{~mm}$, respectively. $\mathrm{RH}$ presents changes on a monthly basis, as Table $\mathrm{V}$ shows, reducing the annual average by $8.0 \%$ with the HadGEM2-ES model for the first period, moving from 81.3 to $73.3 \%$ in the second period with the GFDL-CM3 model. The average annual relative humidity reaches a value of $65.5 \%$, indicating a reduction of about $15.8 \%$ in comparison with the current situation.

Regarding the average annual temperature, an increase of $1.7^{\circ} \mathrm{C}$ with the HadGEM2-ES model is projected in the study area for the period 2041-2060 (RCP 4.5), and of $3.7^{\circ} \mathrm{C}$ with the GFDL-CM3 model for the period 2061-2080 (RCP 8.5). In this regard, IDEAM (2015b) presents results for the average ensemble scenario, where it is suggested that by the end of the century temperature in the state of Guajira could increase $2.3{ }^{\circ} \mathrm{C}$ on average compared to current values. IDEAM considers that the Alta and Media Guajira could have the highest increases, of approximately $2.5^{\circ} \mathrm{C}$, covering the municipalities of Uribia, Manaure and Maicao.

In terms of precipitation, the state of Guajira could have reductions of up to $20 \%$ on average by the end of the century. In particular, to the south of the state and in the municipalities of Rioacha and Dibulla the reductions could vary from 30 to $40 \%$ in relation to the current value (IDEAM, 2015b). Similarly, IDEAM warns that for the periods 2011-2040, 2041-2070 
Table V. Future climatic scenarios (Nazareth station, January [J] to December [D]).

\begin{tabular}{|c|c|c|c|c|c|c|c|c|c|c|c|c|c|}
\hline \multicolumn{14}{|c|}{ HadGEM2-ES, RCP4.5, focused on 2050} \\
\hline $\mathrm{V} / \mathrm{month}$ & $\mathrm{J}$ & $\mathrm{F}$ & M & A & M & $\mathrm{Jn}$ & $\mathrm{Ju}$ & A & S & $\mathrm{O}$ & $\mathrm{N}$ & $\mathrm{D}$ & Sum/avg \\
\hline PCP & 18.7 & 9.1 & 9.7 & 20.1 & 46.2 & 15.3 & 6.0 & 12.1 & 41.3 & 126.2 & 137.8 & 55.7 & 498.2 \\
\hline $\mathrm{T}_{\max }$ & 31.5 & 32.7 & 33.2 & 34.5 & 34.3 & 35.0 & 35.2 & 35.9 & 36.3 & 35.4 & 33.7 & 33.1 & 34.2 \\
\hline $\mathrm{T}_{\min }$ & 23.0 & 23.3 & 22.7 & 24.2 & 24.4 & 25.1 & 25.2 & 23.7 & 24.6 & 23.8 & 23.6 & 22.5 & 23.8 \\
\hline $\mathrm{T}_{\mathrm{avg}}$ & 27.3 & 28.0 & 27.9 & 29.4 & 29.3 & 30.0 & 30.2 & 29.8 & 30.5 & 29.6 & 28.6 & 27.8 & 29.0 \\
\hline $\mathrm{RH}$ & 73.2 & 71.6 & 72.3 & 73.1 & 73.8 & 72.6 & 72.5 & 72.6 & 72.8 & 74.9 & 75.5 & 74.5 & 73.3 \\
\hline \multicolumn{14}{|c|}{ GFDL-CM3, RCP8.5, focused on 2070} \\
\hline $\mathrm{V} / \mathrm{month}$ & $\mathrm{J}$ & $\mathrm{F}$ & M & A & M & $\mathrm{Jn}$ & $\mathrm{Ju}$ & A & $\mathrm{S}$ & $\mathrm{O}$ & $\mathrm{N}$ & $\mathrm{D}$ & Sum/avg \\
\hline PCP & 19.7 & 10.1 & 10.7 & 25.1 & 48.2 & 30.3 & 9.0 & 11.1 & 28.3 & 100.2 & 106.8 & 54.7 & 454.2 \\
\hline $\mathrm{T}_{\max }$ & 33.4 & 34.5 & 34.9 & 36.3 & 36.4 & 37.0 & 37.0 & 38.2 & 38.7 & 37.7 & 35.8 & 35.0 & 36.2 \\
\hline $\mathrm{T}_{\min }$ & 24.9 & 25.0 & 24.5 & 26.1 & 26.6 & 27.3 & 27.1 & 25.9 & 26.9 & 25.6 & 25.3 & 24.4 & 25.8 \\
\hline $\mathrm{T}_{\mathrm{avg}}$ & 29.2 & 29.8 & 29.7 & 31.2 & 31.5 & 32.1 & 32.0 & 32.1 & 32.8 & 31.7 & 30.5 & 29.7 & 31.0 \\
\hline $\mathrm{RH}$ & 65.6 & 64.7 & 65.4 & 65.9 & 65.4 & 64.5 & 65.4 & 63.9 & 63.8 & 66.5 & 67.5 & 66.9 & 65.5 \\
\hline
\end{tabular}

and 2071-2100, increases in temperature could be of $0.9,1.6$ and $2.3{ }^{\circ} \mathrm{C}$, and decreases in precipitation could be of about $14.5,16.57$ and $20.02 \%$, respectively (IDEAM, 2015b). At this point, it is worth mentioning that even though a reduction in precipitation is relatively trivial, the increase in temperature reaches substantial values, which could significantly impact and transform the region, especially because currently precipitation in the study area is rare and temperature is very high.

Lang's index shows a reduction from the current 18.7 to 17.0 in the HadGEM2-ES model for the period 2041-2060 (RCP 4.5), and to 14.5 with the changes projected in the GFDL-CM3 model for the period 20612080 (RCP 8.5). This suggests that, according to the projections found, current conditions in the study area will be exacerbated, which will change its classification to a desert zone as times goes by (Tables I and V).

Furthermore, the future climate classification by the Thornthwaite method, as well as by $\mathrm{I}_{\mathrm{L}}$, show that the study area is still an arid zone, with limited or no excess of water, megathermal and with a low concentration of thermal efficiency (EdA'a'), according to the changes projected by the two models, but conditions become more deficient over time (see Tables IV and VI).

Table VI shows the values obtained for future indexes related to climate classification using the Thornthwaite method, taking into account the changes projected for the HadGEM2-ES model, period 2041-2060 (RCP 4.5), and GFDL-CM3, period 2061-2080 (RCP 8.5).

Tables VII and VIII present the water balance results for the periods analyzed, considering changes in the climatic variables projected for the HadGEM2-ES and GFDL-CM3 models.

When comparing the results from tables III, VII and VIII, it is evident that expected climatic changes exacerbate the deficient conditions in the study area, considerably increasing ETo and Def as time goes by. This is why ETo varies from 1521.1 to $1699.4 \mathrm{~mm}$ with the changes projected by the Had-

Table VI. Indexes and future climate classification.

\begin{tabular}{|c|c|c|c|c|c|}
\hline \multicolumn{3}{|c|}{ HadGEM2-ES, RCP4.5, focused on 2050} & \multicolumn{3}{|c|}{ GFDL-CM3, RCP8.5, focused on 2070} \\
\hline Index & Value & Classification & Index & Value & Classification \\
\hline $\begin{array}{l}\mathrm{I}_{\mathrm{h}}=(\text { Exc } / \text { ETo }) \bullet 100 \\
\mathrm{Ia}=(\text { Def } / E T o) \bullet 100 \\
\mathrm{I}_{\mathrm{m}}=\mathrm{I}_{\mathrm{h}}-\mathrm{I}_{\mathrm{a}} \\
\mathrm{EC}=\left(\mathrm{ETo}_{\mathrm{v}} / \mathrm{ETo}\right) \bullet 100\end{array}$ & $\begin{array}{r}0.0 \\
70.7 \\
-70.7 \\
29.5\end{array}$ & EdA'a' & $\begin{array}{l}\mathrm{I}_{\mathrm{h}}=(\mathrm{Exc} / \mathrm{ETo}) \cdot 100 \\
\mathrm{Ia}=(\mathrm{Def} / \mathrm{ETo}) \bullet 100 \\
\mathrm{I}_{\mathrm{m}}=\mathrm{I}_{\mathrm{h}}-\mathrm{I}_{\mathrm{a}} \\
\mathrm{EC}=\left(\mathrm{ETo}_{\mathrm{v}} / \mathrm{ETo}\right) \cdot 100\end{array}$ & $\begin{array}{r}0.0 \\
77.7 \\
-77.7 \\
29.8\end{array}$ & EdA'a' \\
\hline
\end{tabular}


Table VII. Water balance, RCP 4.5, focused on 2050 (Nazareth station, January [J] to December [D]).

\begin{tabular}{|c|c|c|c|c|c|c|c|c|c|c|c|c|c|}
\hline \multicolumn{14}{|c|}{ HadGEM2-ES } \\
\hline $\mathrm{V} / \mathrm{month}$ & $\mathrm{J}$ & $\mathrm{F}$ & M & A & M & Jn & $\mathrm{Ju}$ & A & S & $\mathrm{O}$ & $\mathrm{N}$ & $\mathrm{D}$ & Total \\
\hline PCP & 18.7 & 9.1 & 9.7 & 20.1 & 46.2 & 15.3 & 6.0 & 12.1 & 41.3 & 126.2 & 137.8 & 55.7 & 498.2 \\
\hline ETo & 114.9 & 127.9 & 150.2 & 136.7 & 146.9 & 157.5 & 168.1 & 172.6 & 160.3 & 139.8 & 118.6 & 105.8 & 1699.4 \\
\hline$\Delta$ & -96.3 & -118.8 & -140.5 & -116.6 & -100.7 & -142.2 & -162.1 & -160.4 & -119.0 & -13.6 & 19.2 & -50.1 & \\
\hline R_Sto & 0.0 & 0.0 & 0.0 & 0.0 & 0.0 & 0.0 & 0.0 & 0.0 & 0.0 & 0.0 & 19.2 & 0.0 & \\
\hline Def & 96.3 & 118.8 & 140.5 & 116.6 & 100.7 & 142.2 & 162.1 & 160.4 & 119.0 & 13.6 & 0.0 & 30.9 & 1201.1 \\
\hline Exc & 0.0 & 0.0 & 0.0 & 0.0 & 0.0 & 0.0 & 0.0 & 0.0 & 0.0 & 0.0 & 0.0 & 0.0 & 0.0 \\
\hline$\Delta$ Sto & 0.0 & 0.0 & 0.0 & 0.0 & 0.0 & 0.0 & 0.0 & 0.0 & 0.0 & 0.0 & 19.2 & -19.2 & \\
\hline ETa & 18.7 & 9.1 & 9.7 & 20.1 & 46.2 & 15.3 & 6.0 & 12.1 & 41.3 & 126.2 & 118.6 & 74.9 & 498.2 \\
\hline ETa/ETo & 0.2 & 0.1 & 0.1 & 0.1 & 0.3 & 0.1 & 0.04 & 0.1 & 0.3 & 0.9 & 1.0 & 0.7 & \\
\hline $\mathrm{R}$ or $\mathrm{U}$ & & & & & & & & & & & $\mathrm{R}$ & $\mathrm{U}$ & \\
\hline
\end{tabular}

Table VIII. Water balance, RCP 8.5, focused on 2070 (Nazareth station, January [J] to December [D]).

\begin{tabular}{|c|c|c|c|c|c|c|c|c|c|c|c|c|c|}
\hline \multicolumn{14}{|c|}{ GFDL-CM3 } \\
\hline $\mathrm{V} / \mathrm{month}$ & $\mathrm{J}$ & $\mathrm{F}$ & M & A & M & Jn & $\mathrm{Ju}$ & A & $\mathrm{S}$ & $\mathrm{O}$ & $\mathrm{N}$ & $\mathrm{D}$ & Total \\
\hline PCP & 19.7 & 10.1 & 10.7 & 25.1 & 48.2 & 30.3 & 9.0 & 11.1 & 28.3 & 100.2 & 106.8 & 54.7 & 454.2 \\
\hline ETo & 123.9 & 141.4 & 166.0 & 150.4 & 166.4 & 177.4 & 185.2 & 194.6 & 182.3 & 156.5 & 131.3 & 113.4 & 1888.8 \\
\hline$\Delta$ & -104.2 & -131.3 & -155.3 & -125.3 & -118.2 & -147.2 & 176.2 & -183.5 & -153.9 & -56.3 & -24.5 & -58.7 & \\
\hline R_Sto & 0.0 & 0.0 & 0.0 & 0.0 & 0.0 & 0.0 & 0.0 & 0.0 & 0.0 & 0.0 & 0.0 & 0.0 & \\
\hline Def & 104.2 & 131.3 & 155.3 & 125.3 & 118.2 & 147.21 & 762 & 183.5 & 153.9 & 56.3 & 24.5 & 58.7 & 1434.6 \\
\hline Exc & 0.0 & 0.0 & 0.0 & 0.0 & 0.0 & 0.0 & 0.0 & 0.0 & 0.0 & 0.0 & 0.0 & 0.0 & 0.0 \\
\hline$\Delta$ Sto & 0.0 & 0.0 & 0.0 & 0.0 & 0.0 & 0.0 & 0.0 & 0.0 & 0.0 & 0.0 & 0.0 & 0.0 & \\
\hline ETa & 19.7 & 10.1 & 10.7 & 25.1 & 48.2 & 30.3 & 9.0 & 11.1 & 28.3 & 100.2 & 106.8 & 54.7 & 454.2 \\
\hline $\begin{array}{l}\mathrm{ETa} / \mathrm{ETo} \\
\mathrm{R} \text { or } \mathrm{U}\end{array}$ & 0.2 & 0.1 & 0.1 & 0.2 & 0.3 & 0.2 & 0.05 & 0.1 & 0.2 & 0.6 & 0.8 & 0.5 & \\
\hline
\end{tabular}

GEM2-ES model for the year in focus 2050, and to $1888.8 \mathrm{~mm}$ with the GFDL-CM3 model for the year in focus 2070, which represents an increase of 11.7 and $24.2 \%$, respectively. Likewise, Def increases by $18.8 \%$ in the first analysis period and by $41.9 \%$ in the second period, while PCP satisfies part of the ETo, becoming ETa, with a reduction of $2.4 \%$ and $11.0 \%$ in the HadGEM2-ES and GFDL-CM3 models for the first and second analysis periods, respectively.

Under the models, periods and scenarios analyzed, it can be observed that with the estimated changes in the HadGEM2-ES model (RCP 4.5, year in focus 2050), only during November there is soil moisture replacement equivalent to $19.2 \mathrm{~mm}$ (which is used in December), while with the estimated changes in the GFDL-CM3 model (RCP8.5, year in focus 2070), there are no months in which water in the soil is replaced. In accordance with the $E T_{a} / E T_{0}$ values shown in Tables VII and VIII, in the first period of analysis only October, November and December would be appropriate to develop some crops that do not require much water. Finally, with the GFDL-CM3 model (2070), the appropriate months would be only October and November.

Table IX summarizes the annual changes expected for the scenarios analyzed.

Figures 4 and 5 illustrate the behavior of monthly PCP, $E T_{0}, E T_{a}$ and Def within the study areas resulting from the analysis of water balance under climate change conditions.

According to the results found, provisional crops such as corn, sorghum, cotton, melon, watermelon, and squash; permanent crops such as avocado, banana, lemon, orange, coconut, lulo, mango, among others, reported in the study area by the Red de Información y Comunicación del Sector Agropecuario Colombiano (Information and Communication Network of the Colombian Agro-livestock Sector, 
Table IX. Changes expected in the water balance.

\begin{tabular}{lcccccc}
\hline $\mathrm{V}$ & $\begin{array}{c}\text { Current } \\
(\mathrm{mm})\end{array}$ & \multicolumn{2}{c}{ HadGEM2-ES, focused on 2050 } & & \multicolumn{2}{c}{ GFDL-CM3, focused on 2070 } \\
\cline { 3 - 4 } \cline { 6 - 6 } & & RCP_4.5 & \% change & & RCP_8.5 & \% change \\
\hline PCP & 510.2 & 498.2 & -2.4 & & 454.2 & -11.0 \\
ETo & 1521.1 & 1699.4 & 11.7 & & 1888.8 & 24.2 \\
Def & 1010.9 & 1201.1 & 18.8 & & 1434.6 & 41.9 \\
Exc & 0 & 0 & 0.0 & & 0.0 & 0.0 \\
ETa & 510.2 & 498.2 & -2.4 & & 454.2 & -11.0 \\
\hline
\end{tabular}

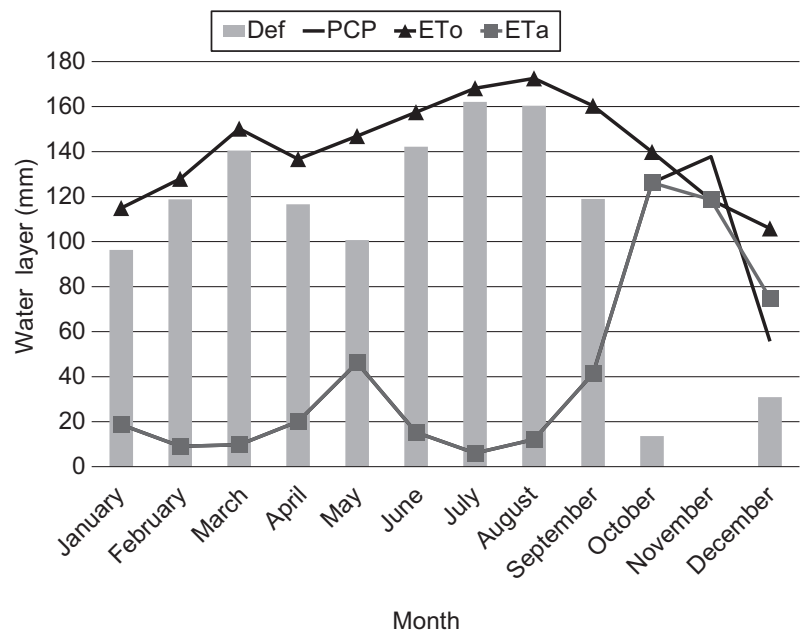

Fig. 4. Water balance, Nazareth-Guajira station (HadGEM2-ES, RCP4.5, year in focus 2050).

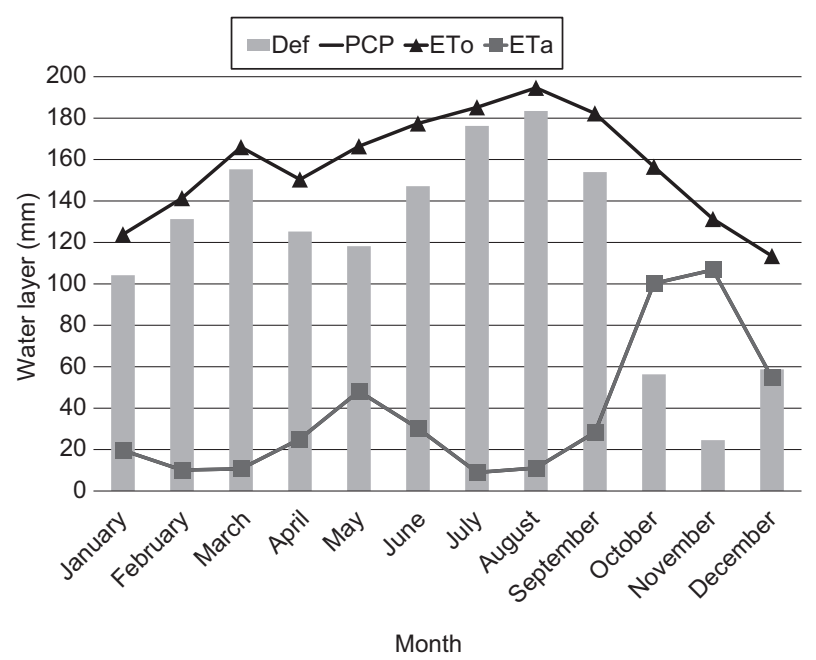

Fig. 5. Water balance, Nazareth-Guajira station (GFDL-CM3, RCP8.5, year in focus 2070).

AGRONET), could be adversely affected by the decrease in precipitation and moisture of soil, and the increase in temperature and ETo.
Moreover, the production, performance and quality of the products cultivated using irrigation systems (e.g., rice) will be affected by the increasingly deficient conditions of the municipality, unless some adjustments are made to the existing irrigation systems, planning of products and the prospect sowing area; even a conversion of products should be considered. Also, progress should be made in investigations concerning the analysis of the viability of rainwater harvesting for those purposes.

IDEAM (2015b) suggests the main effects could be felt by the agricultural and livestock sectors, as well as by subsistence crops, due to the significant increases in temperature throughout the century and to the projected reductions in precipitations. The reduction in the natural supply of water could continue to be one of the main effects on the study area, affecting the health sector due to nutritional factors related to food security.

\section{Conclusions and recommendations}

The increasingly negative changes projected will exacerbate the extreme arid conditions of Uribia and its surroundings, which certainly will significantly transform the flora and fauna components in their current natural ecosystems. This, in turn, will hinder the assessment of future vulnerability and negative impacts of expected climate changes, preventing the design and performance of efficient adaptation proposals.

The access to surface and ground freshwater for different productive uses and consumption (domestic, industrial, agricultural and for other productive sectors) will indeed be affected, causing and increasing substantial economic and social impacts, that could encourage or lead to serious conflicts over the use of water.

The high rates of ETo and the reduction in precipitation and soil moisture can restrict agricultural 
activities, specially irrigated crops, resulting in the crops low or null performance and quality. Likewise, the aquifer recharge and water quality thereof may be negatively affected, since the infiltration rates would be null.

When comparing the baseline vs. future scenarios, climate classifications do not present changes, since the moisture index values vary within the warmer and drier class, precluding the isolation of significant changes in the classification results. However, it is clear that for each scenario the moisture index $\left(I_{\mathrm{m}}\right)$ decreases, enhancing the class characteristics.

It is recommended to conduct research proposals and to create rainwater harvest projects, as well as employing water-efficient cultivation systems in the region, in accordance with the new climate classification or to enhance its climatic characteristics, in order to implement strategies towards the adaptation to climate change and to tackle the potential negative impacts on the sectors and activities that could result affected.

Provided that irrigation systems work efficiently and can supply the current water demand for crops, additional water and the adjustments required to cover at least the projected deficit growth (equivalent to about $18.8 \%$ for the year in focus 2050 [HadGEM2-ES], and $41.9 \%$ for the year in focus 2070 [GFDL-CM3]) should be considered for their future functioning.

Different models were used for two periods, since they were selected from a range of future scenarios for the years 2050 and 2070. The HadGEM2-ES model proved to be the most optimistic for the study region with an RCP of 4.5 by 2050, while the GFDL-CM3 model, with an RCP of 8.5 by 2070 , represented the most pessimistic condition. In other words, the study presents the most and least adverse situations, according to the different scenarios studied.

\section{Acknowledgments}

Authors would like to thank the Programa Nacional de Proyectos para el Fortalecimiento de la Investigación, la Creación y la Innovación en Posgrados de la Universidad de Colombia 2013-2015, for the financial support provided for the investigation development and the human talent training.

\section{References}

Almorox J., 2003. Climatología aplicada al medio ambiente y agricultura. Escuela Técnica Superior de Ingenieros Agrónomos, Madrid, 201 pp.
Bates B. C., Z. W. Kundzewicz, S. Wu and J. P. Palutikof (Eds.), 2008. Climate change and Water. Technical paper. Intergovernmental Panel on Climate Change, Geneva, 210 pp.

Döll P., 2009. Vulnerability to the impact of climate change on renewable groundwater resources: a global-scale assessment. Environ. Res. Lett. 4, 035006, doi:10.1088/1748-9326/4/3/035006.

FAO, 2009. Evapotranspiración del cultivo. Guías para la determinación de los requerimientos de agua de los cultivos. Organización de las Naciones Unidas para la Agricultura y la Alimentación, Roma, 322 pp.

Fu G., S. P. Charles and J. Yu, 2009. A critical overview of pan evaporation trends over the last 50 years. Climatic Change 97, 193-214, doi:10.1007/s10584-009-9579-1.

IDEAM, 2010. Estudio nacional del agua 2010. Instituto de Hidrología, Meteorología y Estudios Ambientales. Bogotá, 421 pp.

IDEAM, PNUD, MADS, DNP, CANCILLERÍA, $2015 \mathrm{a}$. Nuevos escenarios de cambio climático para Colombia 2011-2100. Herramientas científicas para la toma de decisiones, nivel nacional-regional. Tercera comunicación nacional de cambio climático. Bogotá, $15 \mathrm{pp}$.

IDEAM, PNUD, MADS, DNP, CANCILLERÍA, 2015 b. Nuevos escenarios de cambio climático para Colombia 2011-2100. Herramientas científicas para la toma de decisiones. Tercera comunicación nacional de cambio climático. Bogotá, 60 pp.

IPCC, 2007. Cambio climático 2007. Informe de síntesis. Contribución de los grupos de trabajo I, II y III al Cuarto Informe de Evaluación del Grupo Intergubernamental de Expertos sobre el Cambio Climático. Ginebra, 104 pp.

IPCC, 2013. Cambio climático 2013. Bases físicas. Resumen para responsables de políticas. Contribución del Grupo de Trabajo I al Quinto Informe de Evaluación del Grupo Intergubernamental de Expertos sobre el Cambio Climático. Ginebra, 34 pp.

IPCC, 2014. Climate change 2014. Impacts, adaptation, and vulnerability. Part A: Global and sectorial aspects. Contribution of Working Group II to the Fifth Assessment Report of the Intergovernmental Panel on Climate Change (C.B. Field, V. R. Barros, D. J. Dokken, K. J. Mach, M. D. Mastrandrea, T. E. Bilir, M. Chatterjee, K. L. Ebi, Y. O. Estrada, R. C. Genova, B. Girma, E. S. Kissel, A. N. Levy, S. MacCracken, P. R. Mastrandrea and L. L. White, Eds.). Cambridge University Press, $1132 \mathrm{pp}$. 
Jiménez Cisneros B. E., T. Oki, N. W. Arnell, G. Benito, J. G. Cogley, P. Döll, T. Jiang and S. S. Mwakalila, 2014. Freshwater resources. In: Climate change 2014. Impacts, adaptation, and vulnerability. Part A: Global and sectorial aspects. Contribution of Working Group II to the Fifth Assessment Report of the Intergovernmental Panel on Climate Change (C.B. Field, V. R. Barros, D. J. Dokken, K. J. Mach, M. D. Mastrandrea, T. E. Bilir, M. Chatterjee, K. L. Ebi, Y. O. Estrada, R. C. Genova, B. Girma, E. S. Kissel, A. N. Levy, S. MacCracken, P. R. Mastrandrea and L. L. White, Eds.). Cambridge University Press, pp. 229-269.

Kundzewicz Z. W., L. J. Mata, N. W. Arnell, P. Döll, P. Kabat, B. Jiménez, K. A. Miller, T. Oki, Z. Sen and I. A. Shiklomanov, 2007. Freshwater resources and their management. In: Climate change 2007. Impacts, adaptation, and vulnerability. Contribution of Working Group II to the Fourth Assessment Report of the Intergovernmental Panel on Climate Change (M. L. Parry, O. F. Canziani, J. P. Palutikof, P. J. van der Linden and C. E. Hanson, Eds.). Cambridge University Press, pp. 173-210.
McVicar T. R., T. G. Van Niel, M. L. Roderick, L. T. Li, X. G. Mo, N. E. Zimmermann and D. R. Schmatz, 2010. Observational evidence from two mountainous regions that near-surface wind speeds are declining more rapidly at higher elevations than lower elevations: 1960-2006. Geophys. Res. Lett. 37, L06402, doi:10.1029/2009GL042255.

Miralles D. G., T. R. H. Holmes, R. A. M. de Jeu, J. H. Gash, A. G. C. A. Meesters and A. J. Dolman, 2011. Global land-surface evaporation estimated from satellite-based observations. Hydrol. Earth Syst. Sci. 15, 453-469, doi:10.5194/hess-15-453-2011.

Van Vuuren D. P., K. Riahi, R. Moss, J. Edmonds, A. Thomson, N. Nakicenovic, T. Kram, F. Berkhout, R. Swart, A. Janetos, S. K. Rose and N. Arnell, 2012. A proposal for a new scenario framework to support research and assessment in different climate research communities. Global Environ. Chang. 22, 21-35, http:// dx.doi.org/10.1016/j.gloenvcha.2011.08.002.

Wang A., D. P. Lettenmaier and J. Sheffield, 2011. Soil moisture drought in China, 1950-2006. J. Climate 24, 3257-3271, http://dx.doi.org/10.1175/2011JCLI3733.1. 


\section{Annexes}

A1. Moisture index $\left(\mathrm{I}_{\mathrm{m}}\right)$

\begin{tabular}{lcllccl}
\hline \multicolumn{3}{c}{ Humid climates $\left(\mathrm{I}_{\mathrm{m}}>0\right)$} & & \multicolumn{3}{c}{ Dry climates $\left(\mathrm{I}_{\mathrm{m}}<0\right)$} \\
\cline { 1 - 2 } \cline { 5 - 7 } \multicolumn{1}{c}{ Value } & Symbol & Denomination & & Value & Symbol & Denomination \\
\hline $\mathrm{I}_{\mathrm{m}}>100$ & A & Perhumid & & $\left(0 \geq \mathrm{I}_{\mathrm{m}}>-33,3\right)$ & $\mathrm{C}_{1}$ & Dry subhumid \\
$100 \geq \mathrm{I}_{\mathrm{m}}>80$ & $\mathrm{~B}_{4}$ & Very humid & & $\left(-33,3 \geq \mathrm{I}_{\mathrm{m}}>-60\right)$ & $\mathrm{D}$ & Semiarid \\
$80 \geq \mathrm{I}_{\mathrm{m}}>60$ & $\mathrm{~B}_{3}$ & Humid & & $\left(-100 \geq \mathrm{I}_{\mathrm{m}}>-60\right)$ & $\mathrm{E}$ & Arid \\
$60 \geq \mathrm{I}_{\mathrm{m}}>40$ & $\mathrm{~B}_{2}$ & Moderately humid & & & & \\
$40 \geq \mathrm{I}_{\mathrm{m}}>20$ & $\mathrm{~B}_{1}$ & Slightly humid & & & & \\
$20 \geq \mathrm{I}_{\mathrm{m}}>0$ & $\mathrm{C}_{2}$ & Moist subhumid & & & & \\
\hline
\end{tabular}

A2. Seasonal variation of the effective humidity

\begin{tabular}{|c|c|c|c|c|c|}
\hline \multicolumn{3}{|c|}{ Indexes of excess of humidity $\left(\mathrm{I}_{\mathrm{h}}\right)$ for $\mathrm{C} 1, \mathrm{D}$ and $\mathrm{E}$} & \multicolumn{3}{|c|}{ Indexes of aridity $\left(\mathrm{I}_{\mathrm{a}}\right)$ for $\mathrm{A}, \mathrm{B}$ and $\mathrm{C} 2$ climates } \\
\hline Range & Symbol & Denomination & Range & Symbol & Denomination \\
\hline $0<$ Ia $<10$ & d & $\begin{array}{l}\text { Limited or no excess } \\
\text { of water }\end{array}$ & $0<$ Ia $<16.7$ & $\mathrm{r}$ & $\begin{array}{c}\text { Little or no lack of } \\
\text { water }\end{array}$ \\
\hline $10<\mathrm{Ia}<20$ & s & $\begin{array}{l}\text { Moderate excess of } \\
\text { water in winter }\end{array}$ & $16.7<$ Ia $<33.3$ & s & $\begin{array}{c}\text { Moderate lack of water in } \\
\text { summer }\end{array}$ \\
\hline $10<\mathrm{Ia}<20$ & $\mathrm{w}$ & $\begin{array}{l}\text { Moderate excess of } \\
\text { water in summer }\end{array}$ & $16.7<$ Ia $<33.3$ & $\mathrm{w}$ & $\begin{array}{c}\text { Moderate lack of water in } \\
\text { winter }\end{array}$ \\
\hline $\mathrm{Ia}>20$ & $\mathrm{~s}_{2}$ & $\begin{array}{l}\text { Large excess of } \\
\text { water in winter }\end{array}$ & $\mathrm{Ia}>33.3$ & $\mathrm{~s}_{2}$ & $\begin{array}{l}\text { Considerable lack of } \\
\text { water in summer }\end{array}$ \\
\hline $\mathrm{Ia}>20$ & $\mathrm{w}_{2}$ & $\begin{array}{l}\text { Large excess of } \\
\text { water in summer }\end{array}$ & $\mathrm{Ia}>33.3$ & $\mathrm{w}_{2}$ & $\begin{array}{l}\text { Considerable lack of } \\
\text { water in winter }\end{array}$ \\
\hline
\end{tabular}

A3. Index of thermal efficiency

\begin{tabular}{lclccc}
\hline ETo Range $(\mathrm{mm})$ & Acronym & Climatic type & ETo Range $(\mathrm{mm})$ & Acronym & Climatic type \\
\hline ETo $>1140$ & $\mathrm{~A}^{\prime}$ & Megathermal & $427<E T o \leq 570$ & $\mathrm{C}^{\prime}{ }_{2}$ & Second mesothermal \\
$997<E T \mathrm{O} \leq 1140$ & $\mathrm{~B}^{\prime}{ }_{4}$ & Fourth mesothermal & $285<E T o \leq 427$ & $\mathrm{C}^{\prime}{ }_{1}$ & First mesothermal \\
$885<E T o \leq 997$ & $\mathrm{~B}^{\prime}{ }_{3}$ & Third mesothermal & $142<E T o \leq 285$ & $\mathrm{D}{ }^{\prime}$ & Tundra \\
$712<E T o \leq 885$ & $\mathrm{~B}^{\prime}{ }_{2}$ & Second mesothermal & ETo $<142$ & E' & Glacial \\
$570<E T o \leq 712$ & $\mathrm{~B}^{\prime}{ }_{1}$ & First mesothermal & & & \\
\hline
\end{tabular}

A4. Thermal efficiency concentration in summer

\begin{tabular}{lclccl}
\hline EC (\%) & Acronym & $\begin{array}{l}\text { Climatic type } \\
\text { (concentration) }\end{array}$ & EC (\%) & Acronym & $\begin{array}{l}\text { Climatic type } \\
\text { (concentration) }\end{array}$ \\
\hline EC $<48$ & $\mathrm{a}^{\prime}$ & Low & $68>\mathrm{EC} \geq 61.6$ & ${ }^{\prime}{ }_{1}$ & Moderate \\
$51.9>$ EC $\geq 48$ & $\mathrm{~b}^{\prime}{ }_{4}$ & Moderate & $76.3>\mathrm{EC} \geq 68.0$ & ${ }^{\prime}{ }_{2}$ & High \\
$56.3>$ EC $\geq 51.9$ & $\mathrm{~b}^{\prime}{ }_{3}$ & Moderate & $88>\mathrm{EC} \geq 76.3$ & $\mathrm{c}^{\prime}{ }_{1}$ & High \\
$61.6>$ EC $\geq 56.3$ & $\mathrm{~b}^{\prime}{ }_{2}$ & Moderate & $\mathrm{EC}>88$ & $\mathrm{~d}^{\prime}$ & Very high \\
\hline
\end{tabular}

